УДК 342.9

DOI https://doi.org/10.32849/2663-5313/2020.5.21

Валентин Галунько,

докт. юрид. наук, професор,

головний науковий співробітник

Науково-дослідного інституту публічного права

Юрій Буглак,

канд. юрид. наук,

старший науковий співробітник

Науково-дослідного інституту публічного права

\title{
ЮРИДИЧНИЙ ЗМІСТ ПОЛІТИЧНОЇ КОРУПЦІї В УКРАЇНІ
}

Мета статті полягає в тому, щоб на основі методів наукового дослідження, використовуючи доктринальні положення, погляди на ию проблему вчених, вітчизняного та зарубіжного законодавства, публічистичних матеріалів, а також власного досвіду з протидї корупиії сформувати риси та категорійне визначення політичної корупиії в юридичному аспекті. У статі розкрита юридична природа, риси та категорійне визначення політичної корупчії в юридичному аспекті. Доведено, що вона має своїм базисом реальні багаторазово повторювані суспільні відносини, коли провідною рисою вищих посадових осіб держави є прагнення служити приватному інтересу, а не інтересам суспільства та/або банальна продажність з метою наживи. Визначено, що політична корупція в юридичному аспекті - ие здійснені високопосадовиями держави корупиійні діяння, за які нормами права передбачені санкиіі. Наголошено, що політична корупиіі є вершиною і самим небезпечним видом корупиії, однак не єдиною. Адже поряд із нею, як правило, існує управлінська корупщія, корупчія на рівні бізнесу, корупція на рівні громадських організацій, приватного і пов'язаного з ним комунального сервісу (освіта, медицина) тощо. Крім того, треба зазначити, що не належаить до політичної корупиї протиправна діяльність високопосадовиів щодо переслідування політичних опонентів, професійних прав журналістів та грубого порушення прав і свобод громадян. З'ясовано, що метою політичної корупиії насамперед є не збагачення окремих осіб, а прихід до публічної влади і ї утримання. Хоча ми знаємо, що деякі високопосадовиі приходили до влади з метою банального збагачення. Зроблено висновок, що юридичні чинники протидії політичній корупиії є найбільш дієвою і жорсткою вершиною піраміди боротьби із нею, при цьому основне навантаження щодо запобігання їй має лягати на плечі громадянського суспільства та ЗМI, які свойми громадськими, журналістськими та політичними засобами мають відправляти корумпованих високопосадовиів за межі публічної влади, а ті політичні сили, які не самоочищаються від корупчіонерів, - на політичне узбіччя.

Ключові слова: високопосадовці, корупційні діяння, корупція, публічний інтерес, санкції.

Постановка проблеми. У системі гуманітарних цінностей право обирати собі публічних чиновників, які зобов'язані чесно й ефективно, відповідно до принципу верховенства права забезпечувати права, свободи та законні інтереси громадян, є провідним. Проте через свою низьку правосвідомість і політичну культуру, а також маючи практично безмежні можливості, з погляду пересічних громадян, щодо збагачення, високопосадовці у будь-якій державі схильні до зловживань своїм владним становищем. Якщо їх не контролювати і не притягувати до політичної та юридичної відповідальності, більшість із них рано чи пізно починають служити не публічному, а власному приватному і корпоративному інтересу. Такі діяння отримали в науковій і публіцистичній літературі лаконічну назву «корупція».

В Україні ця проблема стоїть більш гостро, ніж в інших країнах. Адже століття бездержавності на генетичному рівні прищепили значній частині наших громадян філософію життя, згідно з якою найбільшою цінністю для них є не держава, яка майже завжди була чужою та окупаційною, а сім'я, родина, близькі та земляки. Максимум, на кого звертали свій позитивний вплив наші пращури, це були колеги по війську та праці. Відповідно коли вихідці з українських земель, завдяки своєму розуму і титанічні праці, пробивалися на високі посади, то насамперед вони, що є логічним, турбувалися не про державу, якій формально служили, а про свої 
інтереси. На жаль, після отримання своєї державності та вже не першої зміни політичної еліти ситуація залишається складною. Ставлення до власної держави значної кількості наших чиновників як до чужої.

Це приводить до негативних наслідків для громадян України. Інвестиції у Україну ідуть мляво, право власності захищене неналежно, рейдерство стало буденним явищем Як результат легальні доходи українців є одними із найбільш низьких в Свропі, продовжується демографічний спад кількості населення, трудова міграція стала чинником, що прямо впливає на національну безпеку. Особливо небезпечною є політична корупція, яка роз'їдає нашу державу із самого верху. Без їі мінімізації годі говорити про успіхи в інших сферах суспільного життя нашого суспільства.

Проблема протидії політичній корупції стоїть гостро, однак у вітчизняній науковій літературі до сьогодні немає сталого його категорійного визначення. Зрозуміло, що відсутній і законодавчий іï опис. Усе це приводить до того, що більшість політичних корупціонерів уникають юридичної відповідальності за політичні корупційні діяння, а іншу частину громадян, які не можуть бути суб'єктами таких діянь, безпідставно звинувачують в них. Це є неприпустимим, оскільки завдає шкоду як публічному інтересу в цілому, так і окремим конкретним громадянам, права, свободи та законні інтереси яких порушуються.

Аналіз останніх досліджень. До проблеми політичної корупції звертались вітчизняні та зарубіжні вчені I. Амундсен, М. Гетьманчук, В. Грищук, Г. Кохан, I. Кушнарьов, А. Тіньков, Я. Турчин та ін. Проте питання політичної корупції в юридичному аспекті вони не аналізували, а зосереджували свою увагу на більш загальних чи суміжних викликах.

Мета статті полягає в тому, щоб на основі методів наукового дослідження, використовуючи доктринальні положення, погляди на цю проблему вчених, вітчизняного та зарубіжного законодавства, публіцистичних матеріалів, а також власного досвіду з протидії корупції сформувати риси та категорійне визначення політичної корупції в юридичному аспекті.

Виклад основного матеріалу. Згідно зі словником української мови, «корупція» (лат. corruptio - підкуп) - це підкупність, продажність урядовців і громадських діячів [4]. Західні словники дають таке визначення: корупція - це непристойна або протиправна поведінка з боку владних осіб, спонукання до неправомірних чи протизаконних дій публічних чиновників [2]. У Законі України «Про запобігання корупції» визначено, що корупція - це використання особою, зазначеною у частині першій статті 3 названого Закону, наданих їй службових повноважень чи пов'язаних $з$ ними можливостей 3 метою одержання неправомірної вигоди або прийняття такої вигоди чи прийняття обіцянки/ пропозиції такої вигоди для себе чи інших осіб або відповідно обіцянка/пропозиція чи надання неправомірної вигоди особі, зазначеній у частині першій статті 3 аналізованого Закону, або на їі вимогу іншим фізичним чи юридичним особам з метою схилити цю особу до протиправного використання наданих їй службових повноважень чи пов'язаних з ними можливостей [5]. У свою чергу вітчизняні політологи доводять, що корупція - це злочинна діяльність у сфері політики або державного управління, що полягає у використанні посадовими особами ввірених їм прав та владних можливостей задля особистого збагачення [6].

Без усякого сумніву, усі вище академічні дефініції корупції мають під собою певну політологічну і юридичну основу, а законодавчий опис правових меж корупції важко критикувати. Однак необхідно зазначити, що 3 погляду юриспруденції не виваженою $€$ наведена остання дефініція корупції, у якій вона жорстко прив'язується до злочинної діяльності, їі складниками є виключно політична і управлінська діяльність, а метою тільки збагачення.

3 таким підходом не можна погодитися у повному обсязі. I ми будемо це доводити у наступному матеріалі. А зараз висунемо гіпотези: по-перше, не всяка корупції є кримінально караною, більш того, певний час деяка корупція може взагалі бути юридично не караною, вона може не підпадати під правовий вплив; по-друге, корупція є багатогранним явищем, в якому поряд із політичним та управлінським складниками має місце бізнес та приватна корупція; по-третє, метою корупції є не тільки збагачення, але й прихід до влади і її утримання.

Застосовуючи методи наукового дослідження, використовуючи доктринальні положення, погляди на цю проблему вчених, положення вітчизняного та зарубіжного законодавства, публіцистичні матеріали, а також власний досвід з протидії корупції, розпочнемо доведення висунутих гіпотез 3 акцентом на юридичному аспекті. Адже відомо, що поняття «політична корупція» в Україні не визначене на законодавчому рівні, що призводить до розмитості розуміння її суб'єктного кола, видів дій, які 
підпадають під кваліфікацію політичної корупції тощо [8].

На думку Інге Амундсен, провідного норвезького вченого, який займається проблемами корупції в країнах, які перебувають на початковій стадії розвитку, корупція - це зловживання державними повноваженнями, а політична корупція - це корупція, в якій участь беруть політичні особи [1].

Стаття 3 Закону України «Про запобігання корупції» до категорії осіб, які можуть суб'єктами корупційних діянь, віднесла широке коло осіб, серед яких, на наш погляд, політичними особами є: Президент України, Голова Верховної Ради України, народні депутати України, Прем'єр-міністр України та усі члени Уряду, Голова Служби безпеки України, Генеральний прокурор, Голова ДБР, Голова НАБУ, Голова НАЗК, Голова Національного банку України, Голова Рахункової палати, Голова Верховної Ради Автономної Республіки Крим, Голова Ради міністрів Автономної Республіки Крим, голови обласних та міста Києва і Севастополя державної адміністрації та голови обласних рад, судді Конституційного Суду України, Голова та члени Вищої ради правосуддя, Голова ВККС, судді Верховного суду та Вищого антикорупційного судів [5]. При цьому вони отримують назву «високопосадовці», які формально та/або реально можуть приймати або впливати на прийняття загальнодержавних чи вагомих регіональних політичних рішень.

На думку вчених і юристів американської юридичної фірми USLegal, політична корупція означає зловживання політичною владою з боку урядових лідерів для набуття і накопичення цінностей для приватного збагачення, а також використання політично корумпованих засобів для підтримання і збереження своєї влади. При цьому вони відмежовують від політичної корупції такі протиправні діяння вищої державної влади, як зловживання нею шляхом репресій проти політичних опонентів, спрямування поліції на жорстоке поводження з громадянами. Підкреслюють, що політична корупція відбувається на найвищих рівнях політичної системи. Відповідно, вона має бути відмежована від адміністративної чи бюрократичної корупції. Її також треба відрізняти від корупції у бізнесі та приватному секторі [3].

На їхній погляд, політична корупція може бути у двох формах. Перша полягає в тому, що державні чиновники використовують і зловживають своєю владою шляхом вилучення з приватного сектору, з доходів уряду та 3 економіки в цілому на свою (своїх рідних, близьких) користь значних цінностей.
Шляхами такої політичної корупції $є$ вилучення державних коштів, розтрата, грабіж і навіть клептократія. Друга форма політичної корупції - це така, в якій видобуті ресурси (та державні кошти) використовуються для збереження та розширення влади. Зазвичай вона має форму фаворитизму та політики меценатства. Вона включає в себе розподіл фінансових та матеріальних стимулів, надання вигоди і переваг своїм особам на засадах фаворитизму та політичної вмотивованості [2].

На наш погляд, розуміння наукової природи політичної корупції американськими вченими і юристами є слушним. Однак і у вітчизняній науковій думці до цієї проблематики існують власні підходи.

Так, А. Тіньков доводить, що прив'язка політичної корупції передусім до державного управління є дискусійним питанням. Політична корупція - це не просто корупція в політичній (державній) сфері. Корупція $€$ політичною в тому сенсі, що саме політичні структури роблять можливими або часто навіть вимагають корупційних дій. Політична корупція має прихований та багатоваріантний характер і далеко не завжди є очевидною для пересічного громадянина, дії політичних корупціонерів є універсальними і стосуються різних сфер суспільного життя [7].

На думку I. Кушнарьова, політична корупція - це деструктивний різновид неформальних інститутів підривного партикулярного характеру, який зумовлюе неправомірне використання суб'єктами політичного процесу 3 корисливих мотивів ресурсів влади у позасуспільних інтересах, приватизацію публічних ресурсів за умов слабкості формальних i конструктивних неформальних інститутів. На його погляд, розуміння політичної корупції охоплює звужену кількість протиправних дій, пов'язаних із фінансуванням партій, електоральними зловживаннями, своєрідними «продажами» місць у виборчих списках, голосів депутатів за певну законодавчу ініціативу тощо. Водночас чимало інших дій у політиці можуть кваліфікуватися як корупційні, що потребує законодавчого врегулювання [8].

Іншими словами, I. Кушнарьов переконливо доводить, що далеко не вся корупція $€$ політичною, а також те, що не всі діяння, які мають ознаки політичної корупції, $є$ юридично караними.

Надзвичайно науково глибинними з погляду теорії є міркування щодо наукової природи політичної корупції Г. Кохан, яка доводить, що політична корупція є настільки багатозначним та конфліктним явищем, що політичні дебати з приводу того, що варто 
брати за його основу, ще й досі точаться між представниками різних суспільних галузей $\mathrm{i}$, судячи $з$ його неоднозначності, так і не отримали логічного завершення. Вона доводить, що аналіз моделей вивчення політичної корупції свідчить, що, по-перше, модель як статична одиниця не може охопити явище в динаміці. По-друге, у моделі неможливо відобразити та прорахувати всі прояви політичної корупції, відповідно, оцінка наслідків може бути неточною або неповною. По-третє, зважаючи на комплексність та унікальність явища політичної корупції, за допомогою моделювання найзручніше демонструвати, як функціонуе певна форма, прояв або тип політичної корупції в суспільстві, у певній політичній системі, коли відомі вхідні умови, середовище, кількість учасників, інтереси та ресурси, за які ці гравці змагаються. Визначення поняття політичної корупції і багатозначність цього явища зумовили також виникнення численних типологій політичної корупції. Зокрема, розрізняють хабарництво в торгівлі, патронажну систему, непотизм, кризову корупцію, індивідуальну та колективну, редистрибутивний та екстрактивний типи корупції, а також електоральну корупцію тощо [8].

Вчена Г. Кохан підкреслює, що політична корупція як динамічне явище, яке постійно розвивається, призводить до того, що політичній системі можуть бути властиві різні типи політичної корупції одночасно. Так само змінюється й набір форм політичної корупції залежно від внутрішніх та зовнішніх умов політичного середовища: постійно коливається від інтеграційної до дезінтеграційної, від стабільної до нестабільної тощо. Оскільки, виникаючи за однакових умов, політична корупція в різні проміжки часу може проявлятися по-різному в одному й тому самому місці, це унеможливлюе сталість їі форми. Кожна форма політичної корупції в одній системі може бути поодиноким та хаотичним проявом, а в іншій - набути ознак норми. Незважаючи на це, у політичній науці існує низка типологій політичної корупції та невичерпний перелік ії проявів, проте процес уточнення та доповнення типів і форм політичної корупції триває, особливо під час проведення окремих грунтовних досліджень [9].

Як ми бачимо, вчені-політологи щодо меж політичної корупції зайшли в глухий кут. Ми також розуміємо надзвичайну складність цього феномена, однак стверджуємо, що вона може і має бути описана в певних межах юридичної матерії. Зрозуміло, з деяким рівнем абстракції, коли ми будемо розкривати фактичний іï зміст та 3 певним рівнем достовірності описувати її юридичний складник.
Звернемося до аргументів та фактів, висунутих на користь висунутих гіпотез.

1. Реальні суспільні політичні корупційні відносини завжди будуть випереджувати норми права, які протидіють, запобігають політичній корупції і боряться з нею. Адже не можливо - і це буде грубим порушенням принципу верховенства права - приймати закони, що обмежують права і законні інтереси осіб, ще до того, як ці суспільні відносини виникли. Відповідно, кара за нові види політичної корупції постійно і об'єктивно буде відставати від реального стану речей, якщо антикорупційні заходи на стадії правотворчості будуть недосконалими, а громадянське суспільство - слабким або неактивним у цій сфері. Іншими словами, простого позитивістського шляху вирішення цієї проблеми не існує. Тут потрібне сильне громадянське суспільство, незалежні ЗМІ і, як наслідок, невідворотність політичної відповідальності корупціонерів. Високопосадовець чи політична сила, яка вчасно не позбулась корупціонера, шляхом втрати довіри виборців має безповоротно залишатися на узбіччі політики і публічної влади.

2. Політична корупція є вершиною і найнебезпечнішим видом корупції, однак не єдиним Адже поряд із нею, як правило, існує управлінська корупція, корупція на рівні бізнесу, корупція на рівні громадських організацій, приватного і пов'язаного 3 ним комунального сервісу (освіта, медицина) тощо. Крім того, треба зазначити, що не належить до політичної корупції протиправна діяльність високопосадовців щодо переслідування політичних опонентів, порушення професійних прав журналістів та грубого порушення прав і свобод громадян. Хоча такі дії здебільшого мають ознаки важких злочинних діянь, проте вони належать до інших видів злочинів.

3. Метою політичної корупції насамперед є не збагачення окремих осіб, а прихід до публічної влади і ї̈ утримання. Хоча ми знаємо, що деякі високопосадовці приходили до влади 3 метою банального збагачення. Таким чином, ми вважаємо що усі висунуті на початку статті гіпотези доведені.

\section{Висновки}

Отже, політична корупція в юридичному аспекті характеризується такими рисами:

1) має своїм базисом реальні багаторазово повторювані суспільні відносини, коли провідною рисою вищих посадових осіб держави є прагнення служити своєму (своїх рідних і близьких) приватному або корпоративному інтересу, а не публічним інтересам суспільства та/або банальна продажність з метою наживи; 
2) це будь-які корупційні діяння, що здійснюються вищими посадовими особами, які мають формальні або/та реальні владні повноваження щодо впливу на прийняття загальнодержавних чи великих регіональних політичних рішень;

3) вона має фактичний і юридичний зміст, які не збігаються: спостерігається, як правило випередження фактичного змісту політичної корупції перед юридичним, коли деякі суспільні діяння, які за своєю сутністю $€$ корупційними, ще не знайшли свого правового впливу у санкціях правових норм;

4) не всі зловживання високопосадовців держави $є$ корупційними правопорушеннями, а тільки ті, які відповідають специфічній протиправній меті;

5) такою метою, по-перше, є протиправне утримання влади для себе та своїх фаворитів, по-друге, максимальне вилучення із приватного сектору та публічного бюджету благ;

6) юридичні чинники протидії політичній корупції є найбільш дієвою і жорсткою вершиною піраміди боротьби із нею, при цьому основне навантаження щодо запобігання їй має лягати на плечі громадянського суспільства та ЗМІ, які своїми громадськими, журналістськими та політичними засобами мають відправляти корумпованих високопосадовців ,за межі публічної влади, а ті політичні сили, які не самоочищаються від корупціонерів, - на політичне узбіччя.

Отже, політична корупція в юридичному аспекті - це здійснювані високопосадовцями держави корупційні діяння, за які нормами права передбачені санкції.

\section{Список використаних джерел:}

1. Inge, Amundsen. Political corruption: An introduction to the issues. 1999. URL: https://www. cmi.no/publications/1040-political-corruption (дата звернення: 22.03.2020)

2. Definition of corruption. 2019. URL: https:// www.merriam-webster.com/dictionary/corruption (дата звернення: 28.03.2020)

3. Political Corruption Law and Legal Definition URL: https://definitions.uslegal.com/p/politicalcorruption/ (дата звернення: 28.03.2020).

4. Корупція. Словник української мови. Академічний тлумачний словник (1970-1980). 1973. Toм 4. C. 302. URL: http://sum.in.ua/s/korupcija (дата звернення: 29.03.2020)

5. Про запобігання корупції : Закон України від 14.10.2014 № 1700-VII. URL: https://zakon.rada.gov. ua/laws/card/1700-18 (дата звернення: 29.03.2020).

6. Гетьманчук М., Грищук В., Турчин Я. Політологія : навчальний посібник. Київ: Знання, 2010. 415 c. URL: http://politics.ellib.org.ua/pages-8495. html (дата звернення: 29.03.2020).

7. Тіньков А. Політична корупція в системі державного управління: українські реалії. Політологія і право. 2010. URL: http://visnyk.academy. gov.ua/wp-content/uploads/2013/11/2010-1-32. pdf (дата звернення: 22.03.2020).

8. Кушнарьов I. Політична корупція : порівняльно-політологічна концептуалізація : монографія. Київ: Юридична думка, 2018. 408 с.

9. Кохан Г. Явище політичної корупції: теоретико-методологічний аналіз : монографія. Київ: НІСД, 2013. 232 c

The purpose of the article is to use the methods of scientific research, using doctrinal provisions, opinions on this problem of scientists, domestic and foreign legislation, journalistic materials, as well as their own experience of combating corruption, to form traits and categorical definition of political corruption in the legal aspect. The article reveals the legal nature, features and categorical definition of political corruption in the legal aspect. It has been proved that it has as its basis real multiple repetitive social relations, when the leading feature of the highest officials of the state is the desire to serve the private rather than the public society or sales for profit. It is determined that political corruption in the legal aspect, it is corruption committed by high officials of the state, for which the rules of law provide for sanctions. It is emphasized that political corruption is the pinnacle and most dangerous form of corruption, but not the only one. Because, as a rule, there is usually corruption associated with managerial corruption, business-level corruption, corruption at the level of public organizations, private and related utilities (education, medicine), etc. In addition, it should be noted that the illegal activity of high-ranking officials in the pursuit of political opponents, professional rights of journalists and gross violation of the rights and freedoms of citizens is not related to political corruption. It has been found that the purpose of political corruption is not the enrichment of individuals, but the arrival and retention of public authority. Although we know that some high-ranking officials have come to power for the purpose of banal enrichment. Thus, we believe that all the hypotheses put forward at the beginning of the article are proved. It is concluded that the legal factors to counteract political corruption are the most effective and rigid top of the pyramid of combating it, with the main burden of preventing it should lie on the shoulders of civil society and the media, which by their public, journalistic and political means have to send the media. public authorities, and those political forces that do not purify themselves against corrupt officials on the political sidelines.

Key words: high officials, corruption, corruption, public interest, sanctions. 